\title{
A Study on Utilization Pattern of Farm Ponds Constructed by the Farmers
}

\author{
B. Sidram ${ }^{1 *}$, Shivanand Kammar $^{1}$, Devendra Biraladinni ${ }^{2}$ and Ravi M. Sambrani ${ }^{1}$ \\ ${ }^{1}$ Department of Agricultural Extension Education, \\ ${ }^{2}$ Department of Agricultural Economics, \\ University of Agricultural Sciences, Raichur, India \\ *Corresponding author
}

\begin{abstract}
A B S T R A C T
A study on utilization pattern of farm ponds constructed by the farmers was conducted in Kalyana Karnataka region of Karnataka state (India). The Kalyana Karnataka region includes the six districts of North eastern part of Karnataka state viz. Kalaburagi, Bidar,

Yadgir, Raichur, Bellari and Koppal districts. Among the six districts of Kalyana Karnataka, Raichur district were selected for the study by considering the highest number of farm ponds constructed by the farmers. All the taluks of Raichur district i.e. Raichur, Lingasoor, Devdurga, Sindhanoor and Manvi were selected for the study. Taluk wise list of farmers who constructed farm pond was collected from JDA office Raichur. From the prepared list 24 farmers each taluk were selected by employing simple random sampling technique to form the sample size of 120 . The findings of the study revealed that, most of the farmers used the farm pond for other than irrigation like, farm animal drinking water $(93.33 \%)$, chemical spray $(90.00 \%)$, bund formation $(74.17 \%)$ and land leveling $(60.83$ $\%$ ). With respect to the utilization pattern of farm pond water for irrigation purpose, 31.67 percent of farmers used for one time irrigation whereas very meager percent i.e. 6.67 and 2.50 per cent of the farmers utilized for two time irrigation and three time irrigation, respectively. $37.96,34.44$ and 30.85 per cent farmers have observed that, increase in the productivity in tur, chilli and chickpea crops due to construction of farm ponds.
\end{abstract}

\section{Keywords}

Utilization pattern,

Farm pond,

Irrigation, Kalyan

Karnataka

\section{Article Info}

Accepted:

20 October 2020

Available Online:

10 November 2020

\section{Introduction}

Water is most essential and necessary climatic factors that determine the growth and development of crops and ultimately the yield. Crops need huge amount of water through out there crop period in different time. Crop needs water for the different functions like photosynthesis, absorption, respiration, translocation, nutrient uptake, cell division, etc. farmers have different sources of water to fulfill the water requirement of crop like, Borewell, canal, well, tank, rivers, rain, farm ponds, etc. Each source has its own limitation and period of availability due climatic factors. According to FAO (2011), irrigation typically doubles farm yields and the number of crops grown in one year is increased from one to two. In India out of 159.6 million hectare of total cropped area only 58.13 million hectare is irrigated i.e. 36.42 per cent and remaining 63.58 per cent 
of the crops solely depends on rain and in Karnataka state, total cropped area is 12.2 million hectare and irrigated area is 2.38 million hectare i.e. 19.51 per cent is irrigated. Indian farming is affected by climate change it represents by uneven distribution of rain, droughts, floods and increasing temperature. To overcome from the water scarcity during cropping period many climate change mitigating technologies have are evolved by the scientist one of them is construction of farm ponds. These are the structure constructed with polythene cover to collect and store the rain water which will be used in non rainy days for agriculture purpose. Karnataka Government in the year 2014-15 initiated the Krishi Bhagya Yojane in which farmers given incentives for conservation of soil moisture in their fields, constructing farm ponds, installing diesel or solar pumpsets to lift water and drip or sprinkler system, with objective to promote the farm ponds and better utilization of rain water. This scheme is meant for farmers in rain-fed areas to have irrigation facilities for their dry lands through rainwater harvesting technique.

Raichur district is situated in north-eastern part of Karnataka state. It falls in the northern maidan region, between $15^{\circ} 33^{\prime}-16^{\circ} 34^{\prime}$ North latitudes and $76^{\circ} 14^{\prime}-77^{\circ} 36^{\prime}$ East longitudes and also between the two major rivers namely the Krishna and the Tungabhadra. Raichur district has received a good response by constructing 2273 farm ponds which exceeded the target of 2000 since the inception of the scheme. A sum of Rs. 13.22 crore has been transferred to the bank accounts of beneficiaries as subsidies in the last two years. Officials of the Agriculture Department are now expecting to make further progress in its implementation by covering more farmers in the current year. Lingasugur taluk, most of its area is rain-fed, it has emerged as the top beneficiary with 657 farmers benefitting from the scheme followed by Manvi (551), Sindhanur (546) and Raichur (328). Deodurg, one of the most backward and driest areas in the country which is supposed to get maximum benefits from the scheme, is at the bottom with only 191. Hence, a study was conducted to know the utilization pattern of farm ponds constructed by the farmers in Raichur district.

\section{Materials and Methods}

Population of the study constitutes the farmers who constructed farm ponds under the Krishi Bhagya Scheme from all the five taluks of Raichur District. Taluk wise list of farmers who constructed farm ponds under Krishi bhagya Yojane were obtained from JDA office, Raichur and from ADA office of respective taluks. From the list so prepared 24 farmers from each taluk were selected by employing simple random sampling procedure thus the total simple size for the study constituted 120 farm ponds constructed farmers. Data were collected by personnel interview method using structured interview schedule. The expost-facto research design was used for the study. This design was considered appropriate as the phenomenon had already been occurred. The present study was an empherical one, in which the researcher did not have direct control over independent variables because their manifestations had already been occurred.

The number of respondents selected from each taluk for the study is given in the Table 1 .

\section{Development of schedule to measure utilization Pattern of farm ponds by the Farmers}

Utilization pattern of farm ponds by the farmers was operationalized by framing questions which elicit the purpose of usage of farm ponds since from the construction. The 
data collected about utilization pattern was tabulated by using frequency and percentage.

\section{Operationalisation and measurement of Independent variables}

\section{Age}

It refers to the chronological age of the farmers at the time of investigation. The age of the farmers was recorded as mentioned by them in completed years. The farmers were categorized into three age groups based on the procedure followed by Shilpashree (2011).

\begin{tabular}{|c|c|}
\hline Category & Age (in years) \\
\hline Young & up to 35 \\
\hline Middle & 36 to 50 \\
\hline Old & Above 51 \\
\hline
\end{tabular}

\section{Education}

It refers to the number of years of formal education acquired by the respondents. In this study, the scale developed by Trivedi (1963) was used to measure the educational status of the respondents as given below.

\begin{tabular}{|l|c|}
\hline Category & Score \\
\hline Illiterate & 0 \\
\hline Primary school & 1 \\
\hline Middle school & 2 \\
\hline High school & 3 \\
\hline PUC & 4 \\
\hline Degree/PG & 5 \\
\hline
\end{tabular}

\section{Innovative proneness}

It is referred as a socio-psychological orientation of an individual to get linked or closely associated with change, adopting innovation ideas and practices.

Moulik's (1965) self rating innovative proneness scale was used to measure the innovative proneness of a farmer. The scale consisted of three sets of statements; each set of statement contained three statements with weights 3, 2 and 1 indicating high, medium and low degree of innovative proneness.

Score of 2 was given 'most like' response and 1 for 'least like' response. The scoring was done by summing up the scores of the weights of the most like statements and weights of least like statements. As there were three sets of statements for innovative proneness scale, the sum of scores for the three set was considered as respondents self rating score for innovative proneness. The respondents were categorized into three categories viz., high, medium and low based on mean and standard deviation as the measure of check.

\begin{tabular}{|l|c|}
\hline Category & Score \\
\hline Low & Less than (mean -0.425 SD) \\
\hline Medium & Between (mean \pm 0.425 SD) \\
\hline High & More than (mean +0.425 SD) \\
\hline
\end{tabular}

\section{Management orientation}

In the present study, the management orientation has been operationally defined as the degree to which a farmer is oriented towards farm management comprising of planning, production and marketing functions of the farm. This variable was measured by adopting the scale developed by Samanta (1977). The scale consisted of 18 statements of which six statements for each of planning, production and marketing aspects. The responses were taken on three point continuum i.e. agree, undecided and disagree for each of the statement. The scoring was conceptually unidirectional. The positive statements were given a score of two for agree, one for undecided and zero for disagree. The scoring was reversed in case of negative statements. The range of scores for the scale was 0 to 36 . The total obtained scores of the farmers were categorized as low, medium and high responses using the mean and standard deviation. 


\begin{tabular}{|l|c|}
\hline Category & Score \\
\hline Low & Less than (mean -0.425 SD) \\
\hline Medium & Between $($ mean \pm 0.425 SD) \\
\hline High & More than $($ mean +0.425 SD) \\
\hline
\end{tabular}

\section{Statistical tools and tests used}

The following statistical tools and tests were employed in the analysis and interpretation of data.

\section{Mean}

The arithmetic mean is the sum of the score divided by their number. This measure was used to categorize the dependent and independent variables into low, medium and high categories.

\section{Frequency}

This measure was used to know the distribution pattern of respondent's variable wise and to categorize the farmers in order of importance.

\section{Percentage}

This measure was used for simple comparison. This is worked out by the following formula

Percentage $(\%)=$

[Number of Responded farmers/Total number of farmers (sample)]

\section{0}

\section{Standard deviation}

This measure was used to categorize the dependent and independent variables into low, medium and high categories.

\section{Results and Discussion}

\section{Profile of the farmers}

Age

It is clear from the Table 2 that, majority of the farmers $(45.00 \%)$ belonged to middle aged group i.e. between 36 to 50 years age. Usually farmers of middle aged are enthusiastic, moderately experienced in farming and have more work efficiency than older and younger ones. Further, middle aged farmers possess more physical vigor and shoulder more family responsibility than younger ones.

The results are in line with the findings of Adesope et al.s (2012) who reported that majority of respondents belonged to 41-50 years age old group. Results are contradiction with the findings of Shimul Mondal et al., (2013) who reported that majority of farmers $(74.50 \%)$ were above 50 years age group.

\section{Education}

Majority of the farmers were illiterate (36.67 $\%$ ) followed by formal education up to middle and high school. Non-realization of the influence of formal education in one's life and illiteracy of the parents might have come in the way of getting education. Another contributing reason could be the rural social environment which might not have encouraged their parents to give education to the children. Distance of higher study centres from the village and need for more investment also might have prevented the parents from providing higher education to their children.

The above findings got support from the studies conducted by Kanavi (2000) indicated that majority of farmers were illiterates. However, the above findings are in contradiction with the findings of Asaduzzaman Sarker and Yoshihito (2008). 


\section{Innovative proneness}

Nearly half the number of respondents $(57.50$ $\%$ ) belonged to medium innovative proneness category. The probable reason might be that, majority of farmers were medium to old aged. It is quite obvious to find the data falling under the normal distribution. Resource base of the farmers might have acted as constraint in experimenting or orienting towards innovation.

The results were in line with the results of Thippeswamy (2007). Above results are in contradiction with results of Patil (2008).

\section{Management orientation}

Medium management orientation was found among majority of the respondents (48.33\%). High per cent of respondents fall under medium to low farming experience category, it is understandable to find data tending towards medium management orientation by the farmers.

The results were in line with the results of Raghavendra (2007). However, the above findings were in contradiction with findings of Hanchinal (1999.

\section{Utilization pattern of farm ponds by the farmers}

The data presented in the table 3 clears that, most of the farmers used the farm pond for other than irrigation like, for farm animal drinking water (93.33\%), for chemical spray water $(90.00 \%)$, bund formation $(74.17 \%)$ and land leveling (60.83\%). Majority of the farmers expressed that, they faced scarcity of drinking water to farm animals during non rainy days, hence instead of using the farm pond water to the crops majority have utilized for animal drinking purpose during non rainy days. Farm pond functioning as a best source of water for the farmers to use for chemical spray to the crops, as it reduces drudgery work and also saves the time which is being wasted in bringing water from faraway places. Hence high majority of farmers utilized farm pond water for chemical spray water. The dig out soil instead of shifting to the waste land, it is being best utilized by the farmers for bund formation and also for land leveling in undulated areas.

In relation to the utilization of farm pond for irrigation purpose, 31.67 per cent of farmers utilized the farm pond water for one time irrigation. The size of the farm pond is the major cause for this result, there are different size farm ponds are constructed under the Krishi Bhagya Yojane i.e. $10 * 10 * 3,12 * 12 * 3$, $15 * 15 * 3, \quad 21 * 21 * 3, \quad 18 * 18 * 3, \quad$ and $30 * 30 * 3$ and $31 * 31 * 3$ meter. It was observed in the study area that majority farmers constructed the farm pond size of $10 * 10 * 3$ meter, this might be the reason for the above findings and also it is the farmer choice based on the area, crop and contribution capacity, he decides the size of farm pond to be constructed. The size decides the volume and the volume of water decides the how many time you can use the water for irrigation. Very meager percent i.e. 6.67 and 2.50 percent of the farmers utilized for two time irrigation and three time irrigation, respectively. Those who constructed bigger sized farm ponds and using drip irrigation system are utilized the farm pond for two and three time irrigation of their crops.

\section{Change in cropping pattern due to construction of farm pond}

No cropping pattern change was observed in the study area due to the construction of farm pond. The reason for this might be that, as the study was conducted just three years after the implementation of the project and after implementation of the project the study area 
has got very scanty rainfall and climate change issues might have restricted the famers to shift or change cropping pattern and another reason might be that farmers of that area lack the knowledge regarding the better utilization of farm ponds (Table 4).

Table.1 Taluk wise distribution of respondents

\begin{tabular}{|l|l|c|}
\hline District & \multicolumn{1}{|c|}{ Taluks } & No. of respondents selected \\
\hline Raichur & Raichur & 24 \\
\hline & Manvi & 24 \\
\cline { 2 - 3 } & Lingasoogur & 24 \\
\hline Sindhanoor & 24 \\
\hline & Devadurga & 24 \\
\hline & & $\mathbf{1 2 0}$ \\
\hline
\end{tabular}

Table.2 Profile of the farmers

$\mathrm{n}=120$

\begin{tabular}{|c|c|c|c|}
\hline Sl. No. & Attributes & $\mathbf{F}$ & $\%$ \\
\hline \multirow[t]{4}{*}{1.} & Age & & \\
\hline & Young (less than 35 years) & 22 & 18.33 \\
\hline & Middle (between $36-50$ years) & 54 & 45.00 \\
\hline & Old (more than 50 years) & 44 & 36.67 \\
\hline \multirow[t]{7}{*}{2.} & Education & & \\
\hline & Illiterate & 44 & 36.67 \\
\hline & Primary school & 9 & 7.50 \\
\hline & Middle school & 32 & 26.67 \\
\hline & High school & 21 & 17.50 \\
\hline & PUC & 10 & 8.33 \\
\hline & Degree/Master Degree & 4 & 3.33 \\
\hline \multirow[t]{5}{*}{3.} & Innovative proneness & & \\
\hline & Low innovative proneness & 23 & 19.17 \\
\hline & Moderate innovative proneness & 69 & 57.50 \\
\hline & High innovative proneness & 28 & 23.33 \\
\hline & Mean: $4.30 \quad$ SD: 1.19 & & \\
\hline \multirow[t]{5}{*}{4.} & Management orientation & & \\
\hline & Low $(<26.45)$ & 62 & 51.67 \\
\hline & Medium (26.45-35.41) & 16 & 13.33 \\
\hline & High $(>35.41)$ & 62 & 51.67 \\
\hline & Mean: 28.43 & & \\
\hline
\end{tabular}


Table.3 Utilization pattern of farm ponds constructed by the farmers

\begin{tabular}{|c|l|c|c|}
\hline S1. No. & \multicolumn{1}{|c}{ Category } & F & \% \\
\hline $\mathbf{1}$ & $\begin{array}{l}\text { Irrigation for one time (crops Tur, Cotton, Sorghum and } \\
\text { Millets) }\end{array}$ & 38 & 31.67 \\
\hline $\mathbf{2}$ & $\begin{array}{l}\text { Irrigation for two time (crops Tur, Cotton, Sorghum and } \\
\text { Millets) }\end{array}$ & 8 & 6.67 \\
\hline $\mathbf{3}$ & $\begin{array}{l}\text { Irrigation for three time (crops Tur, Cotton, Sorghum and } \\
\text { Millets) }\end{array}$ & 3 & 2.50 \\
\hline $\mathbf{4}$ & Drinking water for farm animals & 112 & 93.33 \\
\hline $\mathbf{5}$ & Chemical spray & 108 & 90.00 \\
\hline $\mathbf{6}$ & Fishing & 16 & 13.33 \\
\hline $\mathbf{7}$ & Land leveling & 73 & 60.83 \\
\hline $\mathbf{8 .}$ & Bund formation & 89 & 74.17 \\
\hline
\end{tabular}

Table.4 Change in cropping pattern

\begin{tabular}{|c|l|c|c|}
\hline Sl. No. & Category & Crops earlier & $\begin{array}{r}\text { n=120 } \\
\text { Crops introduced due to } \\
\text { farm pond construction }\end{array}$ \\
\hline 1. & Cropping pattern change & No cropping patter change was observed \\
\hline
\end{tabular}

Table.5 Productivity change due to construction of farm pond

\begin{tabular}{|c|l|c|c|c|}
\hline $\begin{array}{c}\text { Sl. } \\
\text { No. }\end{array}$ & \multicolumn{1}{|c|}{ Crops } & $\begin{array}{c}\text { Yield before farm } \\
\text { pond construction } \\
\text { (Quintals/acre) }\end{array}$ & $\begin{array}{c}\text { Yield increase due } \\
\text { to construction of } \\
\text { farm pond } \\
\text { (Quintals/acre) }\end{array}$ & $\begin{array}{c}\text { Percentage } \\
\text { increase or } \\
\text { decrease } \\
\text { (Quintals/acre) }\end{array}$ \\
\hline $\mathbf{1}$ & Sorghum & $10-12$ & $14-15$ & 18.87 \\
\hline $\mathbf{2}$ & Millet (Fox millet) & $6-7$ & $9-10$ & 28.43 \\
\hline $\mathbf{3}$ & Tur (direct sown) & $5-6$ & $8-9$ & 37.96 \\
\hline $\mathbf{4}$ & Chickpea (Spreading) & $4-5$ & $7.5-8$ & 30.85 \\
\hline $\mathbf{5}$ & Ground nut & $13-14$ & $15-16$ & 16.66 \\
\hline $\mathbf{6}$ & Cotton & $4-5$ & $6.5-7$ & 24.77 \\
\hline $\mathbf{7}$ & Chilli & $4-5$ & $6-6.5$ & 34.44 \\
\hline
\end{tabular}

F-Frequency

$\%$-Percentage

Change in productivity due to construction of farm pond

The productivity of the crops like, tur, chilli and chickpea was found to be increased by $37.96,34.44$ and 30.85 per cent, respectively.
These three are the best irrigation responsive crops when you provide one or two irrigation during the critical stages like flowering and pod filling stages will respond well and lead to higher production and productivity (Table $5)$. 
Whereas, 28.43, 24.77, 18.87 and 16.66 per cent increase in the yield was found in foxtail millet, cotton, sorghum and groundnut, respectively. When crop provided with one or two irrigation facility they perform better and assured irrigation during the critical stages will certainly increases the yield.

\section{Implications of the study}

Based on the findings of the research study following implications were drawn.

The findings of the study indicated that there were only about 40.00 per cent of farmers had used the farm pond water for irrigation. Hence, extension efforts need to be strengthened to impart knowledge and skill to best utilize the farm pond water for raising the crops and also for subsidiary activities.

The result of the study shows that, cropping pattern was not changed due to farm pond construction. University/ research scientists need to conduct the research to find out suitable crops for the region with one or two assured rainfall with high returns.

Progressive farmers who have adopted farm pond effectively and efficiently should be used as referent extension person in promotion and motivating farmers to utilize the farm pond construction scheme effectively.

\section{References}

Food and Agriculture Organization of the United Nations (FAO), 2011, Fast facts: The state of world's land and water resources.

Moulik, T. K., 1965, A study of productive values of some factors of adoption of nitrogenous fertilizers and the influence of sources of information on adoption behaviour. Ph.D Thesis, Indian of Agriculture Research Institute, New Delhi.

Samantha, R. K., 1977, Agro-economic, socio-psychological and communication variables associated with repayment behaviour of agricultural credit users of National Bank. Ph. D. Thesis, Bidhan Chamsia Krishi ViswaVidyalaya, Kalyani, West Bengal.

Shilpashree, B.S., 2011, A Prophylactic Study on Awardee Farmers in North Karnataka. M.Sc.(Agri.) Thesis, Univ. Agric. Sci., Dharwad.

Trivedi, G., 1963, Measurement and analysis of socio-economic studies of rural families. Ph.D. Thesis, Indian Agric. Res. Inst., New Delhi.

\section{How to cite this article:}

Sidram, B., Shivanand Kammar, Devendra Biraladinni and Ravi M. Sambrani. 2020. A Study on Utilization Pattern of Farm Ponds Constructed by the Farmers. Int.J.Curr.Microbiol.App.Sci. 9(11): 2614-2621. doi: https://doi.org/10.20546/ijcmas.2020.911.316 